\section{Guidelines for the prevention of endocarditis: report of the working party of the British Society for Antimicrobial Chemotherapy}

April saw the launch of new guidelines on the prevention of endocarditis from the British Society for Antimicrobial Chemotherapy. ${ }^{1}$ The guidance is based on real rather than perceived risk, with the society suggesting that only three groups of patients require cover. The range of dental procedures that have need of cover is also simplified (see Table 1). This means that fewer patients will need antibiotic prophylaxis but the number of procedures necessitating such cover will increase.

Table 1. Prophylaxis for dental procedures

\begin{tabular}{l|l}
\hline $\begin{array}{l}\text { High-risk cardiac factors } \\
\text { requiring antibiotic prophylaxis }\end{array}$ & $\begin{array}{l}\text { Dental procedures } \\
\text { requiring antibiotic } \\
\text { prophylaxis }\end{array}$ \\
\hline Previous infective endocarditis & \\
\hline $\begin{array}{l}\text { Cardiac valve replacement surgery, ie, } \\
\text { mechanical or biological prosthetic } \\
\text { valves }\end{array}$ & $\begin{array}{l}\text { All dental procedures } \\
\text { involving dento-gingival } \\
\text { manipulation }\end{array}$ \\
\hline $\begin{array}{l}\text { Surgically constructed systemic or } \\
\text { pulmonary shunt or conduit }\end{array}$ &
\end{tabular}

1. Gould FK, Elliott TS, Foweraker J, et al. Guidelines for the prevention of endocarditis: report of the working party of the British Society for Antimicrobial Chemotherapy. J Antimicrob Chemother 2006 Jun; 57: 1035-1042. Epub 2006 Apr 19.

\section{Oral Health Specialist Library}

Regular users of the Oral Health Specialist Library (www.library.nhs. uk/oralhealth/) have been greeted by a new-style front page for the site since the end of April. The change is part of the migration of the National Electronic Library for Health to the UK National Health Service (NHS) National Library for Health (NLH) (www.library.nhs.uk/). These moves are linked to the wider National Programme for Information Technology in the NHS. All the specialist libraries (20 in all) housed within the NLH are now based on the same structure.

The NLH aims to be the best health library and information service in the world, delivering a modern, equitable library service to all NHS staff, extending NHS library services to patients and the public for the first time and reaching NHS staff who do not regularly use NHS library services.

The NLH (www.library.nhs.uk/) aims to be the best health library and information service in the world.

\section{Scottish Dental Clinical Effectiveness Programme publishes first guidance document}

The Scottish Dental Clinical Effectiveness Programme, an initiative of the National Dental Advisory group in Scotland, has recently launched its first guideline document. The guideline on sedation in dental practice was launched during a sedation training event in May. The guideline is available on the web at www.scottishdental.org/cep/guidance/dentalsedation.htm and will be considered in more detail in a future issue of the journal.

Evidence-Based Dentistry (2003) 7, 51-52. doi:10.1038/sj.ebd.6400391 